\title{
Editors' Acknowledgments
}

Many people assisted us in bringing this project to fruition. We thank Annette Lareau, who invited us in 2006 to co-organize with her a one-day conference that would present papers highlighting the work and ideas of Arlie Russell Hochschild. The conference, "The Importance of Being Conceptual: Exploring the Sociological Contributions of Arlie Russell Hochschild," which was held during the 2007 Eastern Sociology Society meetings in Philadelphia, provided the rich soil from which the seed for this book grew. A few of the chapters in this book began as papers from that conference. We also thank the Eastern Sociological Society for their support of that event. At an early point in the process, we greatly benefited from Margaret Andersen's astute advice about publishing details and catchy titles-thank you, Maggie. Our introduction to this book benefited immeasurably from careful readings and insightful comments from a number of readers. Specifically, we thank our incomparable colleagues: Mignon Duffy, Margaret K. Nelson, Debra Osnowitz, and Nicholas Townsend, as well as the anonymous outside reviewers. A team of Brandeis University graduate and undergraduate students enthusiastically stepped up to read sections of the book and comment on potential cover art: Clare Hammonds, Yoon-Jin Kim, Vanessa Lopes Munoz, and Desiree Murphy. We are grateful to the dean of arts and sciences at Brandeis, Adam Jaffe, for generously helping to finance the permission fees essential to reprinting some of the articles in the volume, and to Judy Hanley, senior administrator in the sociology department, for her unfailing support and good humor. As anyone who has created an edited collection knows, the formatting of disparate pieces into a unified whole is a necessary but time-consuming job that requires skill and attention to detail; it is an additional gift if the person enjoys reading the material. Vanessa Lopes Munoz is the ideal editorial assistant in all these ways, and we sincerely thank her for her work on this book. Rutgers University Press has been enthusiastic about this book from its inception. We appreciate the 
insights of Adi Hovav, our acquisitions editor, and the full-throttled support from Marlie Wasserman, our editor who saw us through to publication. We are delighted that At the Heart of Work and Family is the first book in Rutgers' new series Families in Focus. We thank our series coeditors, Naomi Gerstel, Rosanna Hertz, and Margaret Nelson, for their wholehearted support of this project.

Acknowledgments are not complete until they mention and thank the folks at home-the "family" of "work and family." Our families create the foundation and context that has shaped our ability to work on this book while practicing our vision of kinship. Anita Garey thanks Nicholas Townsend, Sasha Friedman, TyAnn Garey, Margot Garey, Hannah Lawrence, and Shaaron Garey for their unqualified support-and for the joy they bring to her. Karen Hansen thanks Andrew Bundy, Evan Hansen-Bundy, Benjy Hansen-Bundy, and Eva Hansen for always being there with abundant bear hugs, love, and laughter. Finally, Anita and Karen are thankful for their twenty-five years of friendship and collaboration. 